\title{
Dental Practitioners and their Perceptions Regarding the Use of Antioxidants in the Promotion of Oral Health
}

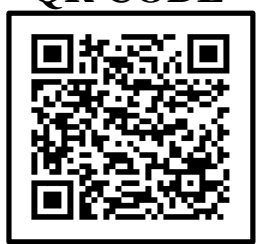

\section{NADIA KHAN ${ }^{1}$, ANAM KHAN², BURSHIDA KHALID², GAURI SHARMA²}

INTRODUCTION: The role of free radicals is well established as a crucial component of the immune system.

AIM: To assess the perception of dental practitioners of Northern and Central India regarding the role of antioxidants in oral health. MATERIALS AND METHOD: A pre-tested and pre-validated online questionnaire was distributed among various dental practitioners in Northern and Central India which consisted of dichotomous responses. Descriptive statistics were used to summarize the data, followed by the Chi square test to check significant differences between the responses. Correlation between responses were analysed through the Spearman's rank correlation. Statistical analysis was done using Statistical Package for Social Sciences version 20 (SPSS 20).

RESULTS: A statistically significant difference was observed among the genders, with females 126 (43.7\%) having lesser knowledge than males $162(56.3 \%)$ regarding the use of antioxidants in their clinical practice. High knowledge scores were observed in 288 $(69.2 \%)$ dental professionals. Postgraduates were found to have $(\mathrm{p}=0.05)$ a higher level of knowledge as compared to graduates. CONCLUSION: The use of antioxidants in dentistry should be increased through the conduction of various CDE programmes. workshops and evidence-based practice guidelines.

KEYWORDS: Antioxidants, Free Radicals, Oral Health, Oral Cancer

\section{INTRODUCTION}

Reactive Oxygen Species (ROS) are unstable in nature as they contain oxygen and that easily reacts with other molecules of a human cell. A build-up of ROS in cells can cause extensive damage to DNA, RNA, and proteins, which may lead to cell death., ${ }^{1,2}$ Sources of free radicals include pollutants, metal ions, high intakes of polyunsaturated fatty acids, drugs, smoking and radiation. These may lead to cell damage resulting in inducement of cancer, neurological diseases, diabetes, vascular diseases, autoimmune diseases, lung cancer, aging and eye diseases. ${ }^{3}$

The presence of an increased number of free radicals leads to "oxidative stress" which affects the oral mucosa in the form of gingivitis and periodontitis. The other factors which can lead to oxidative stress in an individual are dental procedures, bleaching agents, dental cements, exposure to nicotine, alcohol consumption, composite fillings and metals used in dentistry. ${ }^{4}$

Various studies ${ }^{5-7}$ prove the thoery that antioxidants play major role in the prevention of oral cancer as well as premalignant lesions (Leukoplakia, OSMF, Lichen Planus, etc) and can help delay the onset of cancer. A study showing the effect of Lycopene, a commonly used antioxidant in oral cancer has proved that high doses of Lycopene $(8 \mathrm{mg} /$ day) are useful in improvement of oral health. ${ }^{8-9}$

Despite aiding in the prevention of dental diseases, antioxidants are seldom prescribed in dental practice. Therefore, the aim of this study was to assess the perception of dental practitioners of Northern and Central India regarding the role of antioxidants in oral health.

\section{MATERIALS AND METHOD}

The present collected data using an online forms created using google forms and was distributed to various dental practitioners in Northern and Central India using both random and chain-link referral (snowball) sampling from July 2019- November 2019. Firstly, dentists were selected at random and then they were asked to further suggest the names of their colleagues who would like to participate in the study.

(c) Nadia Khan et al. This is an open access article distributed under the terms of the Creative Commons Attribution License CC-BY-NC 4.o, which permits unrestricted use, distribution and reproduction in any medium, provided the use is not commercial and the original author(s) and source are cited. 
The participation in the study was purely voluntary and the dental clinic displayed a QR code for easy access of the questionnaire on the patient's phone itself.

Upon scanning the QR code, the dentist was led to a page which displayed the study objectives, voluntary participation and assurance of the confidentiality of their data. The first page also clearly mentioned that upon clicking the "next" button, the dentists' consent to participate in the study was implied. Responses were only recorded when the patient clicked "submit" at the end of the questionnaire (inclusion criteria) and responses with $\geq 1$ incomplete response was excluded from the analysis. The minimal sample required was 257 and was calculated using OpenEpi online statistical software.

The questionnaire was adopted from Randhawa RK et al.1o and subsequently modified. Details of the dental practitioners were recorded and the questionnaire was divided into two sections. Section A included questions regarding sociodemographic profile and section B included the questions related to the perception of dentists regarding the role of antioxidants in the dentistry.

The responses were obtained using a 5-point likert scale ranging from strongly agree to strongly disagree. High knowledge among dental practitioners was assessed by determining the median of total responses obtained, which served as a "cut-off point. A pilot study was performed on 20 subjects and the data obtained was excluded from the analysis. Cronbach's alpha $(\alpha)$ of the questionnaire was found to be good (o.82).

Descriptive statistics were used to summarize the data, followed by the Chi square test to check significant differences between the responses. Correlation between responses were analyzed through the Spearman's rank correlation. Statistical analysis was done using Statistical Package for Social Sciences version 20 (SPSS 20).11 All significant test were two tailed and p value of less than 0.05 was considered to be statistically significant.

\section{RESULTS}

\section{Total number of participating dentists}

There were a total of 575 responses obtained, out of which 159 were excluded as the data was incomplete. A total of 416 responses were analyzed and the response rate was $(72.3 \%)$

\section{Demographic details of participating dentists (Table 1)}

The present study comprised of 212(50.9\%) males and 204(49.1\%) females. A higher number of subjects $201(48.3 \%)$ belonged to the age group of $20-35$ years whereas the lowest number of subjects 106(25.5\%) belonged to the age group of 35-54 years. Considering their working status, $187(44.9 \%)$ of the subjects were self employed, $115(27.6 \%)$ were employed (by academic institution, other clinics, etc) and 114 (27.5\%) were doing both. Based on the level of education, 163(39.2\%) were post graduates and $253(60.8 \%)$ were graduates.

\begin{tabular}{|c|c|c|}
\hline & $\begin{array}{c}\text { NO. OF } \\
\text { RESPONDENTS } \\
\end{array}$ & $\begin{array}{c}\% \text { OF } \\
\text { RESPONDENTS } \\
\end{array}$ \\
\hline \multicolumn{3}{|c|}{ GENDER } \\
\hline Male & 212 & 50.9 \\
\hline Female & 204 & 49.1 \\
\hline \multicolumn{3}{|c|}{ AGE GROUPS } \\
\hline $20-35 y r s$ & 201 & 48.3 \\
\hline $35-54 y r s$ & 106 & $25 \cdot 5$ \\
\hline$>55 \mathrm{yrs}$ & 109 & 26.2 \\
\hline \multicolumn{3}{|c|}{ WORKING STATUS } \\
\hline $\begin{array}{c}\text { Self- } \\
\text { employed }\end{array}$ & 187 & $44 \cdot 9$ \\
\hline $\begin{array}{c}\text { Employed (by } \\
\text { academic } \\
\text { institution, } \\
\text { other clinic, } \\
\text { etc) } \\
\end{array}$ & 115 & 27.6 \\
\hline Both & 114 & $27 \cdot 5$ \\
\hline \multicolumn{3}{|c|}{ LEVEL OF EDUCATION } \\
\hline $\begin{array}{c}\text { Post } \\
\text { graduation } \\
\text { Graduation } \\
\text { Total }\end{array}$ & $\begin{array}{l}163 \\
253 \\
416\end{array}$ & $\begin{array}{c}39.2 \\
60.8 \\
100\end{array}$ \\
\hline
\end{tabular}

Table 1. Sociodemographic profile of study subjects

\section{Responses of The Subjects Based On The Dichotomous Scale (Table 2)}

It was seen that both the genders were mostly aware of antioxidants and a statistically significant difference along with a strong correlation was seen among both the genders with females 199(197.5\%. p=0.04) being more knowledgeable. No significant differences were seen in the knowledge of the genders when they were asked about the antioxidants present in diet and the human body. 


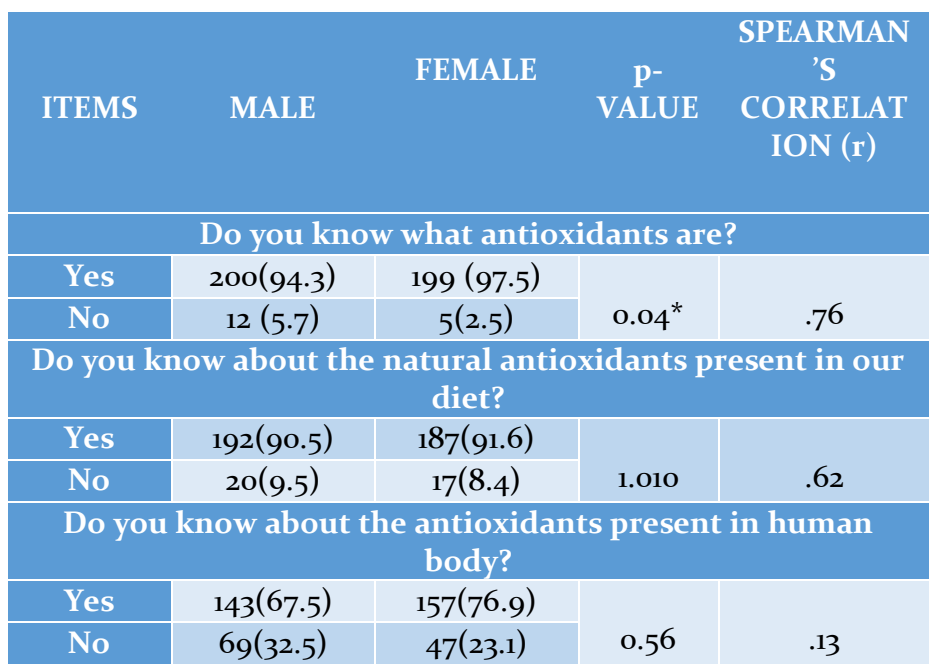

Table 2. Responses of the study subjects regarding their knowledge about antioxidants

Level of knowledge regarding antioxidants among study subjects (Table 3 )

Males $162(56.3 \%)$ had a high knowledge as compared to females 126 (43.7\%). The young dentists $(143,49.6 \%)$ with age group of 20-35 years were having higher level of knowledge. Based on the level of education, the dental professionals who attained their graduate degree 188 (65.3\%) were having higher level of knowledge than those having their master's degree. No statistical differences were observed in any of the responses.

\begin{tabular}{|c|c|c|}
\hline & $\begin{array}{c}\text { LOW LEVEL } \\
\text { OF } \\
\text { KNOWLEDGE } \\
(128,30.8 \%) \\
\end{array}$ & $\begin{array}{c}\text { HIGH LEVEL } \\
\text { OF } \\
\text { KNOWLEDGE } \\
(\mathbf{2 8 8 , 6 9 . 2 \% )} \\
\end{array}$ \\
\hline \multicolumn{3}{|c|}{ Gender } \\
\hline Male & $50(39.1)$ & $162(56.3)$ \\
\hline Female & 78 (6o.9) & $126(43.7)$ \\
\hline \multicolumn{3}{|c|}{ Age groups (in years) } \\
\hline 20- 35 years & $58(45 \cdot 3)$ & $143(49.6)$ \\
\hline $35-54$ years & $15(11.7)$ & $91(31.6)$ \\
\hline$>55$ years & $55(43.0)$ & $54(18.8)$ \\
\hline \multicolumn{3}{|c|}{ Working Status } \\
\hline Self employed & $66(51.6)$ & $121(42.0)$ \\
\hline Employed & $38(29.7)$ & $77(26.7)$ \\
\hline Not employed & $24(18.7)$ & $90(31.3)$ \\
\hline \multicolumn{3}{|c|}{ Level of education } \\
\hline Postgraduates & $63(49.2)$ & $100(34.7)$ \\
\hline Graduates & $65(50.8)$ & $188(65 \cdot 3)$ \\
\hline
\end{tabular}

Table 3. Responses of the study subjects regarding their knowledge about antioxidants
Source of knowledge regarding antioxidants (Table 4)

It was revealed that $50.2 \%$ of dental healthcare personnel's main source of information was the Internet followed by newspaper (29.3\%). Only $13.2 \%$ of the oral health care personnel referred books.

\begin{tabular}{|c|c|}
\hline SOURCE OF INFORMATION & RESPONSES (n, \%) \\
\hline Newspaper & $122(29.3)$ \\
\hline Internet & $209(50.2)$ \\
\hline Books & $55(13.2)$ \\
\hline Any other source & $30(7.3)$ \\
\hline Table 4. Sources of Information about Antioxidants \\
among the study respondents \\
\hline
\end{tabular}

\section{DISCUSSION}

Dental Healthcare professionals play an enormous role in molding the public opinions and beliefs regarding health-related issues and hence, it is crucial that the prescribing fraternity should be well-informed about nutrition and antioxidants present in our diet and its role in maintaining the good oral health. ${ }^{12-13}$

In the present study, there were an equal number of participants. This was because of both genders are now focused in their clinical practice. Majority (48.3\%) of them were in the age group of $20-35$ years due to the reason that in the last ten years, so many new dental colleges have been established in India. ${ }^{14}$

Various studies have shown the role of antioxidants in the caries prevention, and a study done by Shetty et al. ${ }^{15}$ who reported that free radicals in tobacco smoke increase the prevalence of dental caries. Motamayal et al. ${ }^{16}$ revealed that there are association between Total Antioxidant Capacity of saliva and dental caries and this may be helpful in caries prevention. In the present study, high knowledge of antioxidants was seen among $69.2 \%$ of dental professionals.

Finally, when the dental practitioners were asked from where they got the maximum information regarding antioxidants, it was highlighted that their main source of information was from Internet $(50.2 \%)$ followed by newspaper(29.3\%), which are in contradiction to Patil $\mathrm{K}$ et al. whose study reported that majority of graduate $(40 \%)$ and postgraduate dentists(31.3\%) gained their knowledge through journal articles only. ${ }^{17}$ However use of books and newspaper was low it may be due to their busy schedule or lack of interest. 
A probable limitation in this study is social desirability bias as it describes the tendency of survey respondents to answer questions in a manner that will be viewed favorably by others. However, the researchers aimed to reduce this by assuring the respondents of the confidentiality of their data and incorporating a large sample size.

\section{CONCLUSION}

We suggest the organization of various dental educational programmes and evidence based guidelines for prescribing antioxidants in a dental setting.

\section{REFERENCES}

1. Sharma P, Jha AB, Dubey RS, Pessarakli M. Reactive Oxygen Species, Oxidative Damage, and Antioxidative Defense Mechanism in Plants under Stressful Conditions. Journal of Botany 2012;2012: 217037. doi:10.1155/2012/217037

2. Halliwell B, Whiteman M. Measuring reactive species and oxidative damage in vivo and in cell culture: How should you do it and what do the results mean? B J pharmacol 2004;142:231-55.

3. Malele RRS, Sayuni N. Assessment of Knowledge, Attitude And Practice on the Use of Natural Antioxidants Towards Cancer Prevention Among Health Personnel at Muhimbili. RJPBCS 2014;5(1):96279 .

4. Vargas-Koudriavtsev T. Herrera-Sancho OA. Effect of tooth-bleaching on the carbonate concentration in dental enamel by Raman spectroscopy. J Clin Exp Dent. 2017;9(1): e101-e106. doi: 10.4317/jced.53145

5. San Miguel SM, Opperman LA, Allen EP, Zielinski J, Svoboda KK. Bioactive antioxidant mixture promote proliferation and migration on human oral fibroblast. Arch Oral Biol. 2011;56(8):812-22. doi: 10.1016/j.archoralbio.2011.01.001

6. Bhuvaneswari P. Antioxidants in Oral Healthcare. Sai Pavithra R. J. Pharm. Sci. \& Res 2014;6:206-9.

7. Aravindh L, Jagathesh P, Shanmugam S, Sarkar S, Kumar PM, Ramasubramanian S. Estimation of plasma antioxidants beta carotene, vitamin $\mathrm{C}$ and vitamin $\mathrm{E}$ levels in patients with OSMF and Oral Cancer - Indian population. Int J Biol Med Res. 2012;3(2):1655-7.

8. Bhardwaj R, Chaudhary K, Kaur S, Gupta R, Kamal R, Kumar M. Lycopene in oral health. Indian J Oral Sci. 2013;4:125-9

9. Randhawa RK, Gupta N, Arora V, Gupta P. Antioxidants in Oral Health. IJCMR 2015;2(1):53-8.

10. Randhawa RK, Gupta N, Bansal M, Arora V, Gupta P, Thakar S. Perception of dental practitioners regarding the use of antioxidants in oral health. Rocz Panstw Zakl Hig. 2016;67(3):315-20.

10. IBM Corp. Released 2011. IBM SPSS Statistics for Windows, Version 20.o. Armonk, NY: IBM Corp.Carnelio S, Khan SA, Rodrigues G. Definite, probable or dubious: antioxidants trilogy in clinical dentistry. British Dental Journal 2008;204:29-32.

12. Nagelberg RH. Antioxidant Therapy. Dental Economics 2014;104(2):24.

13. Arora K, Chadha VS, Chandrashekar BR, Madan C, Manjunath BC, Moorthy VRR. A knowledge, attitude, and practices study regarding dental floss among dentists in India. Journal of Indian Society of Periodontology 2014;18(30):361-8.

14. Dental Council of India. Available from: http://www.dciindia.gov.in/ [Last Accessed on 15th February, 2020]

15. Shetty AV, Kumari S, Darshana, Geethashri A, Sneha $\mathrm{N}$. Influence of the total antioxidant content of saliva on dental caries. NUJHS 2011;1:1-3.

16. Motamayel FA, Goodarzi TM, Hendi SS, Kasraei S, Moghimbeigi A. Total antioxidant capacity of saliva and dental caries. Med Oral Patol Oral Cir Bucal 2013;18(4):553-6.

17. Patil K, Kumar V, Munoli K. Knowledge and attitude of dental surgeons in India toward ocular complications of intra-oral local anesthesia. J Nat Sc Biol Med 2015;6:286-9o 
Source of support: Nil, Conflict of interest: None declared
Cite this article as:

Khan N, Khan A, Khalid B, Sharma G. Dental Practitioners and their Perceptions Regarding the Use of Antioxidants in the Promotion of Oral Health. Int Healthc Res J. 2020;4(1):10-14. https://doi.org/10.26440/IHRJ/0401.04337

\section{AUTHOR AFFILIATIONS: (*Corresponding Author)}

1. MDS (Oral Pathology and Microbiology)

2. BDS

Private Practitioners and Consultant Dental Surgeon, Teeth Clinic, Sector 66 A, Mohali, Punjab 